\title{
Can Cranioplasty be Effective in Improving Cognitive and Motor Function in Patients with Chronic Disorders of Consciousness? A Case Report
}

\author{
Kronik Bilinç Bozuklukları Olan Hastalarda Kraniyoplasti \\ Yapılması Kognitif ve Motor Isslevi Arttırmakta Etkili Olabilir mi? \\ Bir Olgu Raporu
}

\author{
Francesco CORALLO, Rocco Salvatore CALABRÒ, Antonino LEO, Placido BRAMANTI \\ IRCCS Centro Neurolesi “Bonino - Pulejo", Messina, Italy
}

Corresponding Author: Rocco Salvatore CALABRÒ / E-mail: salbro77@tiscali.it

\begin{abstract}
The "trephined" syndrome is a relatively rare complication after a large skull bone defect, consisting of a sunken skin above the bone defect with neurological symptoms such as severe headaches, mental changes, focal deficits, or seizures. Emerging data show improvements in the patients' neurological status after cranioplasty, i.e. the surgical intervention to repair cranial defects. Herein we report a 55-year-old man who attended our Neurorehabilitation Research Institute for a chronic disorder of consciousness (DOC) due to a severe right nucleo-capsular hemorrhage. His motor and neuropsychological status greatly improved after cranioplasty. Our results confirmed previous reports that cranioplasty may significantly improve neuropsychological and motor function, as evaluated by specific tests, in patients with skull bone defects, and even in patients with DOC.
\end{abstract}

KEYWORDS: Cranioplasty, Minimally conscious state, Cognitive rehabilitation, Disorder of consciousness

\section{öz}

"Trephined" sendromu büyük bir kafatası kemik defektinin nispeten nadir bir komplikasyonudur ve kemik defektinin üzerinde içeri çökmüş deri görünümü ve şiddetli baş ağrıları, zihinsel değişiklikler, fokal defisitler veya havaleler gibi nörolojik belirtilerden oluşur. Elimizdeki veriler, hastaların nörolojik durumunun kraniyal defektlerin onarımı için kullanılan bir cerrahi girişim olan kraniyoplasti sonrasında düzeldiğini göstermektedir. Burada şiddetli sağ nükleo-kapsüler kanama nedeniyle kronik bilinç bozukluğu olan ve Nörorehabilitasyon Araştırma Enstitümüze gelen 55 yaşında bir hastayı sunuyoruz. Hastanın motor ve nöropsikolojik durumu kraniyoplasti sonrasında büyük iyileşme gösterdi. Sonuçlarımız kraniyoplastinin kafatası kemiği defektleri ve hatta bilinç bozukluğu durumu olan hastalarda spesifik testlerle belirlendiği şekilde nöropsikolojik ve motor işlevi önemli ölçüde düzeltebileceğini bildiren önceki raporları doğrulamıştır.

ANAHTAR SÖZCÜKLER: Kraniyoplasti, Minimal bilinçli durum, Kognitif rehabilitasyon, Bilinç bozukluğu

ABBREVIATIONS: CRS-R: coma recovery scale-revised, GCS: Glasgow coma scale, ADL: activities of daily living, IADL: instrumental activities of daily living, FIM: functional independence measure, MMSE: mini mental state examination

\section{INTRODUCTION}

Cranioplasty is the major intervention to repair cranial defects, and it gives relief to psychological drawbacks and increases the social performance in addition to improving motor performance. Although several reconstruction materials are used in cranioplasty, there are no studies able to prove that one is more suitable than another. Therefore, many research topics are focused on developing of both biological and non-biological materials. Cranioplasty is performed mostly after traumatic brain injuries (10). Cancer surgery and the decompressive craniectomies are the leading causes of cranial defects.
On the other hand, contraindications for cranioplasty are the presence of hydrocephalus, infection, and brain swelling.

Before performing a reconstructive cranioplasty, it is recommended to wait from 3 to 6 months in order to prevent the development of devitalized autograft or allograft infections (10). The "trephined" syndrome (or sinking skin flap, SSF) is due to a defect in the skull bone, and it is characterized by neurological symptoms such as seizures, severe headache, focal deficits and cognitive and behavioral changes. Unfortunately, SSF may lead to paradoxical herniation with consequent coma or death (8). 
Patients undergoing cranioplasty may have important and unexpected improvement in cognitive and motor function, although the pathomechanism remains unclear. However, it has been suggested that the decrease of local cerebral compression may improve cerebrospinal fluid hydrodynamics, global cerebral hemodynamics, and thus the metabolism to globally improve performance (1).

There are few studies that demonstrate an improvement in the consciousness of patients in the vegetative or minimally conscious state following cranioplasty (5-9). The possible effects of this breach on the patients' neurological recovery are poorly understood and have been scarcely evaluated until now. The effect of cranioplasty on cognitive and motor functions in severely brain-injured individuals remains controversial (3). Herein we describe the case of a patient in vegetative state (VS) with recovery of consciousness after repositioning of the skull.

\section{CASE PRESENTATION}

In October 2011, a 55-year-old man experienced sudden onset of motor deficits and language difficulties, with

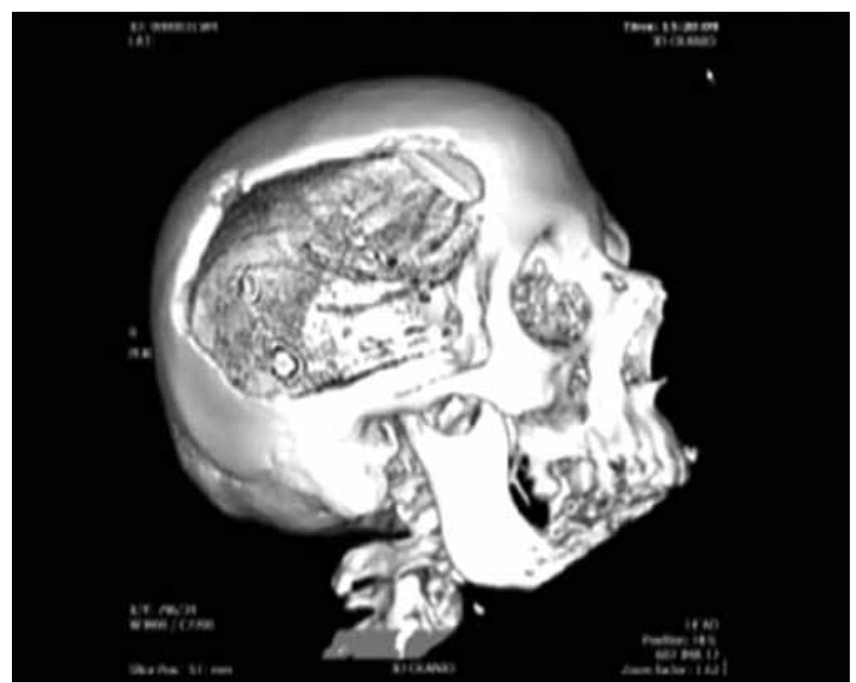

Figure 1: $3 D C T$ reconstruction of the skull defect after craniectomy. consciousness impairment. After he was admitted to the emergency room, a CT scan of the skull showed a massive right-side nucleo-capsular hemorrhage with perilesional cerebral edema. As the clinical conditions worsened, the patient underwent neurosurgery intervention, consisting in decompressive craniectomy, hematoma evacuation and positioning of an intracranial pressure monitoring device. A subsequent brain CT scan showed a significant reduction of the parenchymal herniation through the bony crypt and a near complete reabsorption of the intraventricular blood, while the Angio-CT did not reveal any vascular abnormalities. The patient who was in a VS was then admitted to our Research Institute for an intensive neurological rehabilitation (consisting of motor and cognitive rehabilitation performed twice/day), with a progressive improvement in general and neurological conditions. During the hospitalization he suffered some critical episodes characterized by complex partial seizures, helpfully treated with lamotrigine $(200 \mathrm{mg} /$ day). On June 2012, the patient (who was in a Minimally Conscious State, MCS) was transferred to a Neurosurgery Unit to undergo cranioplasty. Prior to placement of the case the patient has performed a CT scan 3D (Figure 1).

In July 2012, the patient returned to our institution to continue his rehabilitation treatment (Figure 2). The neurological examination and the scores obtained by proper clinical scales and neuropsychological tests before and after the intervention of cranioplasty showed a significant improvement in consciousness and global cognitive performances. We also found that the ADL and IADL index score, which is a daily activities functional score, significantly improved (Figure 3 ). Moreover, a partial autonomy of everyday-life activity was reached at discharge (December 2012), beside a further improvement in motor and cognitive function.

\section{DISCUSSION}

This case demonstrates a clear evidence of a possible recovery of cognitive, behavioral and motor function after a severe acquired brain injury, partially related to a proper cranioplasty. Moreover, we observed a slow and only partial recovery in the activities of daily living, as well as in some residual motor and cognitive impairment. The neurological basis

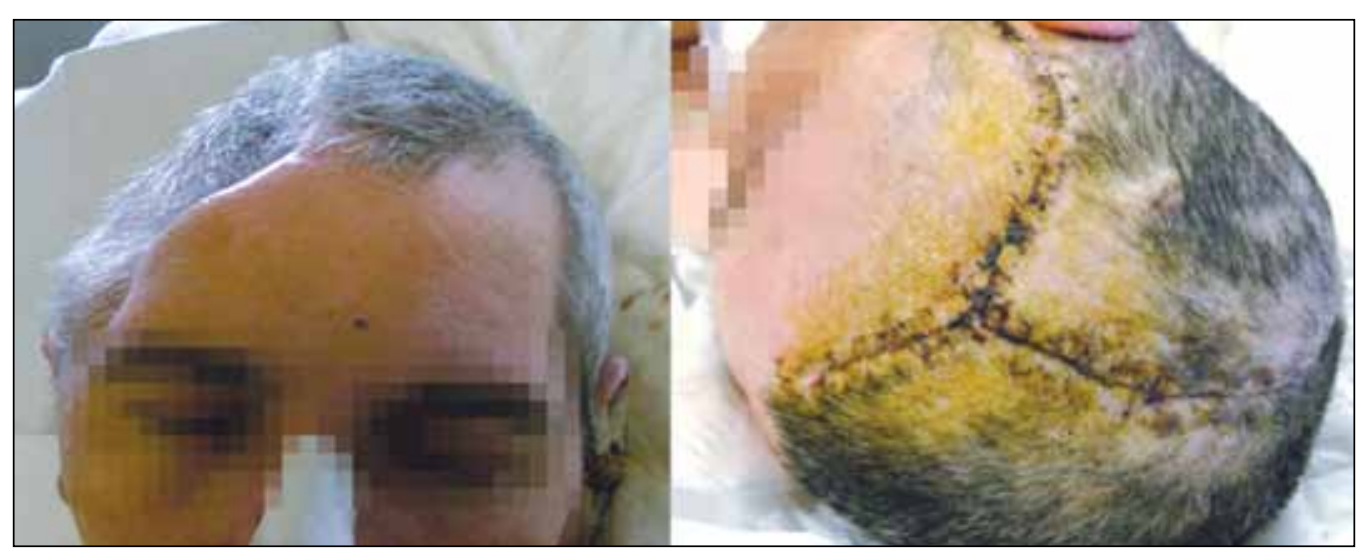

Figure 2: The patient's skull before and after cranioplasty. 


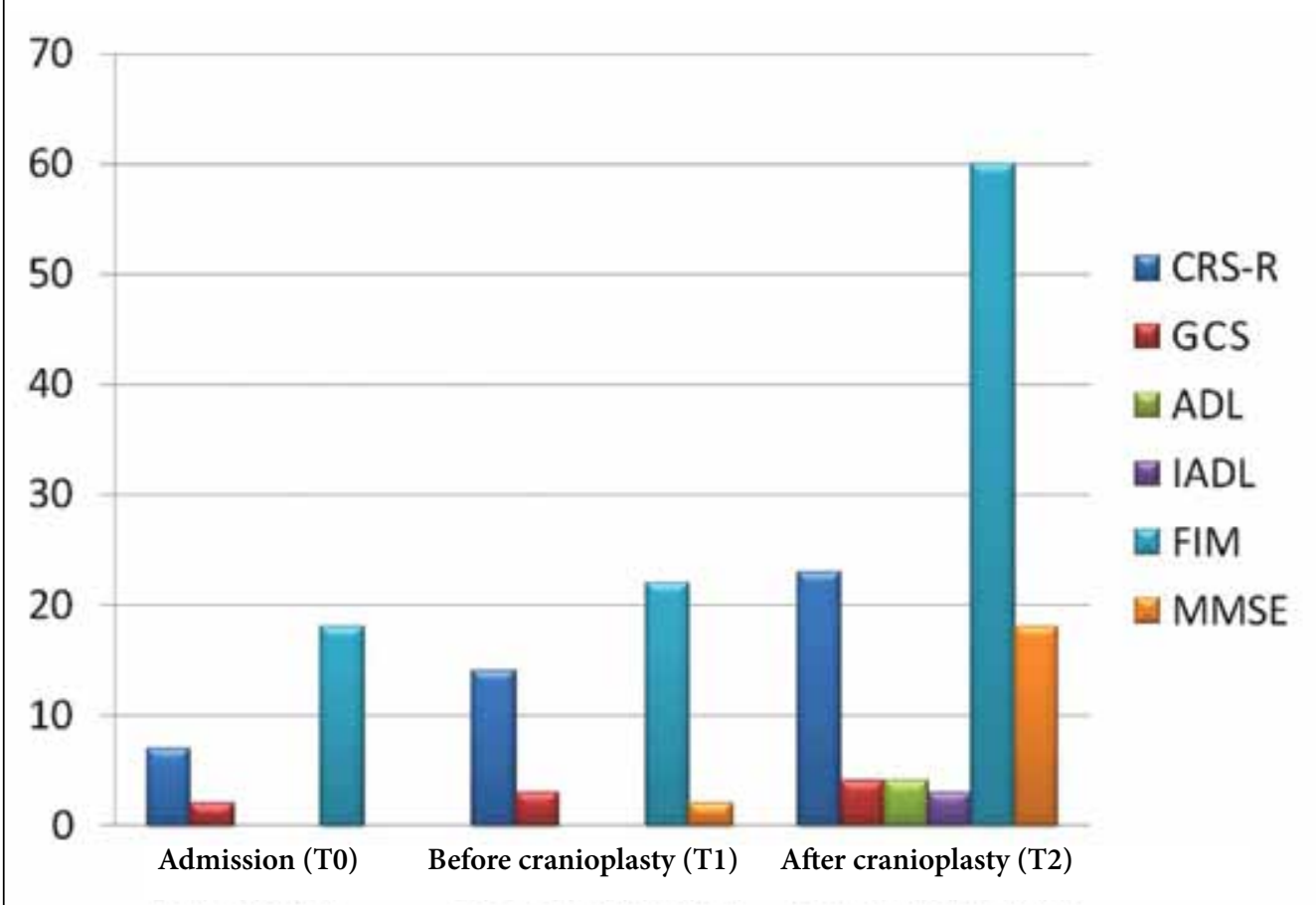

Figure 3: Clinical scales and neuropsychological tests, performed at admission (TO), before (T1) and after craniplasty (T2). for late recoveries remains unknown, although unexpected VS improvements have been observed in patients with the use of dopaminergic or GABAergic drugs or with intrathecal baclofen. In this case, no specific drug was administered and only two procedures, in the opinion of the authors, represents the potential candidates influencing the recovery of consciousness, i.e. early and long-term rehabilitation and cranioplasty (9).

The potential improvements of neuropsychological function after cranioplasty have been shown in several studies, although the mechanism remains unclear, even though some authors have attributed neurological and cognitive deficits to the atmospheric pressure transmitted through the cranial cavity (2). This hypothesis is partly confirmed by the findings that cranioplasty improves the neuropsychological state and motor function in patients with bone defects of the skull, maybe thanks to the improvement of the cerebral blood flow (CBF) $(5,7)$.

To date, only another case of a patient in VS with recovery of consciousness following cranioplasty has been described, confirming our hypothesis of a positive effect of this method on the cognitive performances, although many other variables must be taken into account (9). It is known that early and long-term rehabilitation can affect the outcome in severely brain injury, even in VS and MCS patients. In this case, multidisciplinary programs and intensive rehabilitation were started early, and then continued uninterruptedly throughout the period of unconsciousness and impaired response. Indeed, it is possible that the long-term rehabilitation helped to recover the function until the unexpected success, but it is very doubtful that a more appropriate model of motor and cognitive stimulation, as expected by multidisciplinary rehabilitation programmers, may also influence the recovery of consciousness inducing mechanisms of neuronal plasticity. Unfortunately, so far no clinical hypotheses can be invoked to better support our findings. Beyond these two speculative cues (cranioplasty and rehabilitation), no better explanation can be considered to better understand the amazing recovery of consciousness described either by Sancisi et al. (9) or by our group.

A deeper understanding of the factors influencing the outcomes in VS/MCS individuals is urgent, and any possible method leading to the patient's recovery must be used before discharge.

The repair of the cranial defect provides a clear benefit to the patients in terms of neurological improvement in many cognitive domains as well as in quality of life. Thus, larger and multicenter studies should be fostered to confirm these interesting and promising findings.

\section{REFERENCES}

1. Chibbaro S, Vallee F, Beccaria K, Poczos P: The impact of early cranioplasty on cerebral blood flow and its correlation with neurological and cognitive outcome. Prospective multicentre study on 24 patients Rev Neurol 169(3): 240-248, 2013

2. Cho H, Kim CH, Kim JH, Kim JM: Paradoxical herniation after decompressive craniectomy for acute subdural hematoma. J Korean Neurosurg Soc 40(1): 51-53, 2006

3. Di Stefano C, Sturiale C: Unexpected neuropsychological improvement after cranioplasty: A case series study. $\mathrm{Br} \mathrm{J}$ Neurosurg 26(6): 827-831, 2012 
4. Estraneo A, Moretta P:Predictors of recovery of responsiveness in prolonged anoxic vegetative state. Neurology 80(5): 464-470, 2013

5. Kuo JR, Wang CC, Chio CC, Cheng TJ: Neurological improvement after cranioplasty - analysis by transcranial doppler ultrasonography. J Clin Neurosci 11(5):486-489, 2004

6. Lombardi F, Gatta G: The Italian version of the Coma Recovery Scale-Revised (CRS-R) Funct Neurol 22:47-61, 2007

7. Maekawa M, Awaya S, Teramoto A: Cerebral blood flow before and after cranioplasty performed during the chronic stage after decompressive craniectomy evaluated by Xenonenhanced computerized tomography CBF scanning. No Shinkei Geka 27: 717-722, 1999
8. Romero FR, Zanini MA, Ducati LG, Gabarra RC: Sinking skin flap syndrome with delayed dysautonomic syndrome An atypical presentation. Int J Surg Case Rep 4(11): 1007-1009, 2013

9. Sancisi $E$, Battistini A: Late recovery from post-traumatic vegetative state. Brain Inj 23(2):163-166, 2009

10. Schiff ND: Recovery of consciousness after brain injury: A mesocircuit hypothesis. Trends Neurosci 33(1):1-9, 2010 